\title{
The Influence of Gamification on Online Consumers' Attitude and Intention to Purchase Fast Moving Consumer Goods
}

\author{
Kaouther Dhahak ${ }^{\mathrm{a}}$, Farid Huseynov ${ }^{\mathrm{b}}$
}

Abstract: In the world of business, gamification is considered to be a quick-rising technique, with numerous organizations embracing gaming techniques and game-style rewards to grow customer interest and engagement and influence customer's attitude toward their brands. This study has investigated the factors of gamification influencing online customers' attitudes and intentions to purchase fast moving consumer goods (FMCG). This study presents a research model based on the Technology Acceptance Model (TAM) and previous empirical studies. There are seven factors in this model which are perceived ease of use, perceived usefulness, perceived enjoyment, perceived social influence, perceived trust, attitude and intention. Four out of seven factors are independent variables and attitude is mediator variable in the proposed research model. This study used quantitative research techniques and study data was collected from 200 participants who downloaded the gamified Oreo application, played with the app for certain duration, and later filled the study questionnaire. Collected data were analyzed with confirmatory factor analysis (CFA) and structural equation modeling (SEM) in AMOS statistical software. In this study, it has been found that perceived usefulness, perceived social influence, and perceived enjoyment positively influence attitude. However, it has been found that perceived ease of use does not influence attitude and perceived usefulness does not influence purchase intention. Trust and perceived ease of use have been found to positively influence perceived usefulness yet perceived enjoyment has not been found to influence perceived usefulness.

Keywords: Gamification, Fast Moving Consumer Goods, Technology Acceptance Model, Brand Attitude, Purchase Intention

JEL: M31, O32, Q55

\section{Introduction}

In non-game environments, the gamification concept and its mechanics are quickly emerging in business particularly in marketing. Although in its beginning, the dynamics and gamification techniques can be easily transferred from the gaming software origin to the commercial world. This concept has been used in the past 15 years to enhance user's motivation and engagement and also to change the behavior of the user in different environments. Many large companies have implemented gamification in different industries to motivate their employees as Blue Wolf does or to keep their customers engaged (Nike and Pokémon GO). Gamification has already been recognized in many and different fields such as education, business, social networks, medicine, etc. However, it is still not that popular within FMCG domain. This research investigates the effect of gamification on customer purchase intention, and also tries to understand how it influences

a Master Student, Istanbul Aydin University, Faculty of Economics and Administrative Sciences, Department of Business Administration, Istanbul, Turkiye, kaouther.dhk@yahoo.com (ORCID ID : 0000-0002-9125-3542)

b Asst. Prof., PhD., Gebze Technical University, Faculty of Business Administration, Department of Management, Kocaeli, Turkiye, fhuseynov@gtu.edu.tr (ORCID ID : 0000-0002-9936-0596) 
consumers' attitude toward FMCG. To meet this end, an Oreo application was used with a questionnaire as an assessment instrument. Data were collected from citizens living in Turkey and then were analyzed to finalize the results. The Technology Acceptance Model (TAM) was used in this study; it is one of the most influential models of technology acceptance, known by two main factors that influence the intention of individuals to use new technologies: perceived usefulness and perceived ease of use (Davis, 1989). From two well-known theories, TAM and Theory of Reasoned Action (Fishbein \& Ajzen, 1975), it can be understood that the actual use of a technological system is directly or indirectly influenced by the intention, attitude, perceived ease of use and perceived usefulness. In the information systems' application, many researchers have successfully used TAM to predict behavioral intent regarding information technologies (e.g. Legris, Ingham, \& Collerette, 2003; Ramayah \& Jantan, 2003; Ramayah, Lam, \& Sarkawi, 2003). TAM has become the most powerful influential theory in the field of information systems. It has been argued that TAM seems to account for $40 \%$ to $50 \%$ of user acceptance (Park, 2009). Li (2014) argues also that TAM is a well-accepted theory in the context of accepting an information system (IS) that clarifies online consumer behavior in the case of individual approval or rejection of technology.

\section{Literature Review}

\subsection{Gamification}

The term "gamification" is an old term, it appeared in the beginning of the 2000s (Marczewski, 2013), but it has become popular in the early 2010s (Deterding et al., 2011; Werbach \& Hunter, 2012). Gamification has been defined as "the use of game design elements in non-game contexts" (Deterding, Khaled, Nacke, \& Dixon, 2011). As stated in the definition of Seaborn and Fels (2015), the goal of gamification is to give a gameful experience but in a context other than of the game and to motivate a particular behavior or a pertinent idea in the real world. Also, Deterding et al. (2011) added that the gamification concept is similar to the concept of serious games but has different purposes than the normal anticipated within the framework of an entertaining game. Indeed, gamification was born thanks to the incredible success of games. Games have been used throughout history and have frequently entertained the motivated people and engaged in some way for centuries. Superficially there may be a great similarity between games and gamification, like the sharing of structural elements, but an important distinction lies in the different purpose of their use. A game generally forms an end in itself; however, gamification forms a means to an end.

The central idea is to carry the "building blocks" from games and apply them in real-life situations, frequently to motivate particular behaviors inside the gamified situation. The majority of authors view gamification as a promising and innovational concept that might be used in a diversity of contexts (Zichermann \& Cunningham, 2011; Werbach \& Hunter, 2012; Zichermann \& Linder, 2013).

Gamification has been considered to have benefit for both business companies (improving viscidity and customer loyalty, and therefore sales) and customers (as a legitimate means of adding value to a service). As a result, gamification quickly became a major marketing trend. As explained by Hamari (2013), gamification is a new marketing thinking type, where complete games are considered as a way to add value to the product's web pages. Besides, when the service provider's goal is education, more serious games may be implemented for this purpose. Hamari (2013) also argued that loyalty programs with an amalgamation of game mechanisms can provide important benefits to customers, who demonstrate that customer loyalty.

\subsection{Motivation of Gamification}

Gamification has been considered as a motivational tool to promote user engagement. Indeed, the key to gamification success is engaging people emotionally and motivating them to achieve their goals. Gamification involves the addition of game elements such as points, levels, badges, rankings and other items that are considered an external reward mechanism, as they are used to provide positive reinforcement that can motivate the behavior of a user.

Generally, there are two types of human motivation: intrinsic and extrinsic. Extrinsic motivation refers to behavior motivated by an external factor that pushes the person to do something in the hope of 
winning a reward, such as money, fame, grades or praise (Harry, 2014). In this case, you engage a behavior not because you like it, or because you find it satisfying, but to get something in return or to avoid something unpleasant. However intrinsic motivation refers to behavior motivated by internal rewards like enjoyment, positive feelings (Harry, 2014). In other words, the behavior of the person is motivated by his inner desire to do something that is naturally satisfactory to him. The individual sets his own goals, creates expectations and the reinforcement is achieved by achieving the goals he has set himself. According to what Deci, Koestner and Ryan (1999) have said, intrinsic motivation was thought to be more desirable when it has a greater learning outcome's results. Since the gamification marketing process generally engages in giving users information about products or brands, it encourages participants to learn more and to join or pursue action. In the case of this research, engage in gamification because of its effects. Thus, when the motivation behind people is intrinsic, they have a real inclination/willingness for the activity itself and appreciate it immensely.

Since the gamification marketing process typically aims to provide users information about products or brands, it encourages participants to learn more and to join or pursue an action. Two fundamental theories of self-motivation were directed at understanding the psychological aspects associated with engagement behavior or participation. The 16 basic desires' theory (Reiss, 2000) has been used to understand innate human desires as well as the foundations of collaborative engagement in business, thus supplying a useful tool for the analysis and prediction of human behavior, including order, power, curiosity, economy, independence, honor, idealism, acceptance, status social contact, revenge, family, romance, eating, tranquility and physical activity. Besides, the theory of self-determination (SDT) by Deci and Ryan (1985) has defined a motivational to help to understand how human behavior initiates and regulates. It acknowledges the social and environmental conditions that affect personal will and commitment to activities. This theory as well merges cognitive motivations and psychological needs that describe the need for autonomy, competence and relationships. It is therefore interesting to mark that these two theories have modeled a close connection between the basic desire of people, social aspects and cognitive factors. In the gamification context for marketing, if cognitive motivations and social needs are intrinsically linked to "play", users might be affected by these behavioral or attitudinal factors. Moreover, within game studies, it is clear that motivational and emotional engagement during the game can be enormous. The gamification basic idea is not just to use this motivational power of games for entertainment purposes of the game itself, but to use it for other intentions as well. As a few latest researches has shown, gamification systems are nowadays being employed with various purposes as influencing behaviors or attitudes, promoting safe driving behavior, motivating physical training, improving the quality of life and improving learning in education (e.g. McGonigal, 2011). However, despite the fact that gamification is frequently assumed to be an efficient tool to enhance motivations, research and investigation of the motivations for gamification are rare, mostly for marketing use.

\subsection{Effects of Gamification}

Concerning the effects of gamification, according to previous research, brands exposition within video game would have an impact on players' memory to the brand (Nelson, 2002; Grigorovici \& Constantin, 2004). Also, when marketing or advertising interact, they can be categorized into two acceptance contexts: passive interactions and active interactions. The majority of television programs and films are classed in passive interactive media, which are comparatively difficult to obtain immediate responses from the public. Lee and Faber (2007) stated that video games are interactive media as players can interact and they must have willing interactions, actions, and responses. As Acar (2007) said, people are by nature more fascinated and interested in active interaction rather than passive interaction. In such cases, gamification with multimedia may as well presents particular features of interactivity between users and sensorial submersion, which makes it more alive and closer to the public than other media. Besides, it might be effortless and more effective for marketers to create and put targeted brands in the process. Gamification can be an innovative platform for incorporating brand messages compared to traditional marketing tools. Xu (2010) said that gamification may be an enjoyable and a fun way to allow consumers to accept brands. Moreover, gamification for marketing may enable the brand message to repeat during the process. In relation to traditional marketing tools, gamification does not have a time limit or space in branded products or services. 
Several other traditional media usually make the diffusion once; therefore the marketing message has a lower opportunity to be seen by people. Also, just like games, gamification has interactive entertainment. Through powerful interactions, gamification could strengthen the sense of belonging and enhance the recognition of a brand. Whenever interacting with other participants or with the system in the gamification process, participants will get different types of emotions and experiences. This will directly or indirectly impact brand evaluation (Herrewijn \& Poels, 2013). Finally, people enjoy rivaling with each other, playing games and winning. Within gamification, they can also compete and get awards. People appreciate the participating process in an event competing with rewards, even with small prizes, virtual or symbolic.

Gamification takes advantage of the game's features and applies them to marketing use. The willingness of people to compete and gain awards can incentivize them to increase and improve their fidelity to their brand, product or service. Gamification has the ability to stimulate people's engagement, but not many researchers have incorporated it into practical research, especially in the context of marketing. A research was done about employees has shown that gamification makes the work process to be more enjoyable and the works can actively be involved and entertaining when combining games and tasks. In the same way, the use of game-style training can also encourage engaging work in a dynamic environment.

Games-style courses are a popular way of transferring formation to teams or individuals (Fletcher \& Tobias, 2006), suggesting that gamification is playing a progressively significant role in engaging training. Companies are increasingly embracing manipulation in the expectancy of improving their business performance.

\subsection{FMCG and Gamification}

In recent months, major grocery brands have been striving to make interesting deals with game franchises, online sports organizers and professional gamers (Glotz, 2019). There is the new agreement between Coca-Cola and Overwatch League of Activision Blizzard. Kellogg's has announced the signature of a groundbreaking three-year contract with the Major League Soccer sport initiative. And P\&G's Head \& Shoulders has registered for the gaming player RAMZES666 as a new brand ambassador. The interest of grocery stores for games is not new. But it's accelerating. Advertising experts in the fields of gaming and sports report growing interest from non-endemic sponsors (the gaming industry speaks for companies that do not produce games or gaming equipment), largely led by FMCG. And most importantly, this interest is starting to spread beyond the more typical brands of energy drinks and snacks. Glotz (2019) said that their investigation with Harris Interactive indicates that $35 \%$ of UK gamers buy food and drink especially for playing video games. This figure grows to $55 \%$ for players between the ages of 18 and 24 . Industry experts, such as Alex Beckett, associate director of Mintel Food \& Drink, report that FMCG companies are "more and more fascinated by the relationship between gaming and food." As the gaming market has matured, its demographic profile has moved away from the adolescent gamers' stereotype to include older gamers with a lot of disposable income.

\section{Theoretical Model and Hypotheses Formulation}

The research model of this study (Figure 1) was developed based on the existing literature (Yang, Asaad, \& Dwivedi, 2017). A TAM (Davis, 1989) model was used in this study and new variables were added. These variables are perceived enjoyment (Yang et al., 2017) which is considered to be one of the most important motivational aspects for gameplay in-game studies (Hsu \& Lu, 2007; Li, 2014), perceived social influence (Yang et al., 2017), and perceived trust (Leeraphong \& Mardjo, 2013). There are four independent factors and three dependent factors in this model. Independent variables are perceived ease of use, perceived social influence, perceived enjoyment, and perceived trust. On the other side, dependent variables are perceived usefulness, attitude and purchase intention. This research model was developed in order to examine the marketing benefits of gamification while exploring the relationship between brand attitude and purchase intention behavior and the relationships among the study variables are tested in order to measure to which extent they impact each other. 
Figure 1. Conceptual Framework of the Study

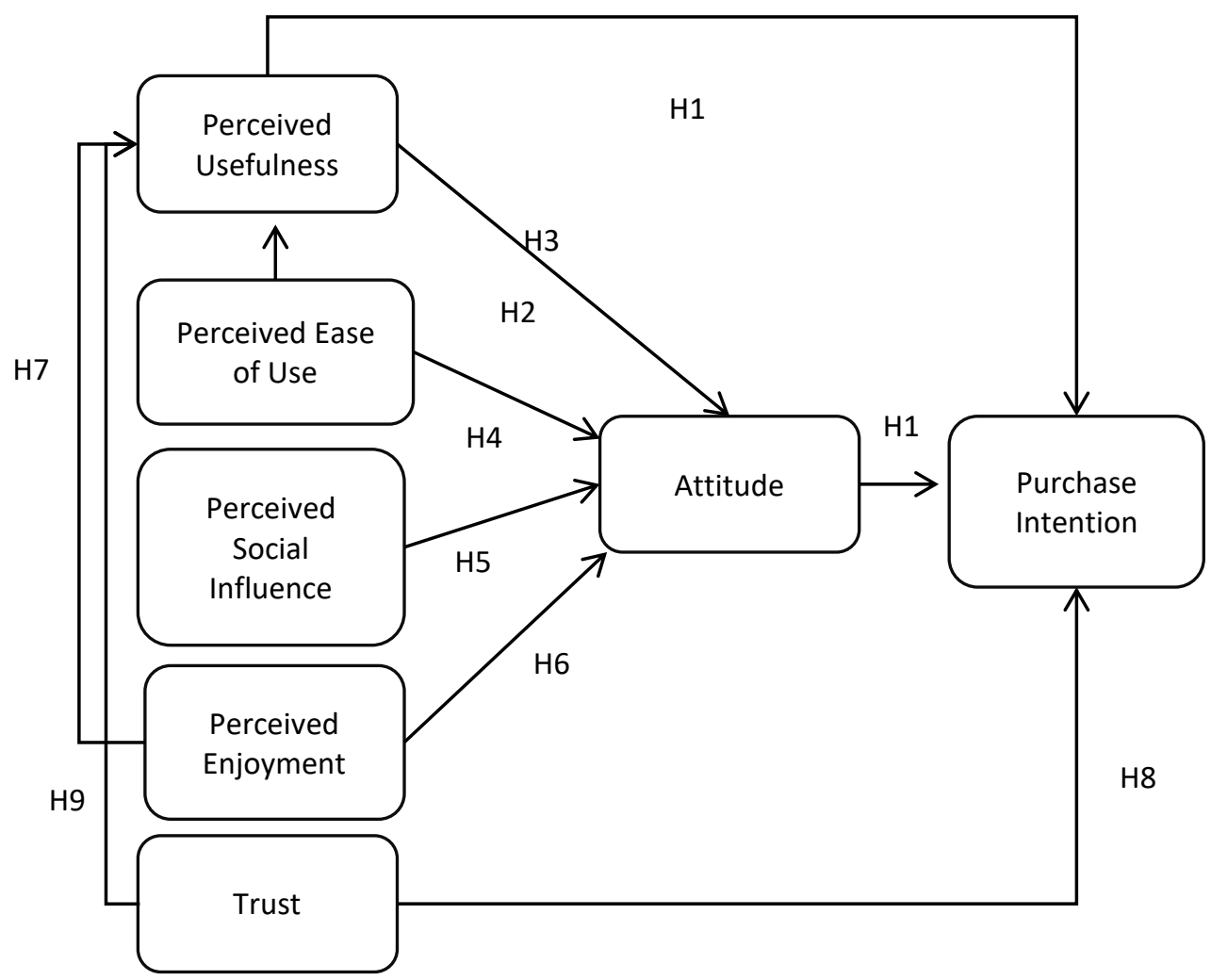

\subsection{Perceived Usefulness}

Perceived Usefulness (PU) is known as one of the independent concepts of the Technology Acceptance Model (TAM). It was defined by Davis et al. (1989) as the degree to which an individual thinks that the use of a specific technology would enhance their professional performance in a given organizational context. Koufaris (2002) affirmed the positive connection among perceived usefulness and purchase intention from the online setting by analyzing the online customers' expectations to make unplanned purchases through e-commerce. Hassanein and Head (2007) analyzed a similar relationship and affirmed it by observing the data from three different groups on their social presence in the e-commerce context. Further, a few studies have indicated that perceived usefulness straightforwardly impacts purchase intention in e-commerce contexts (Gefen \& Straub, 2000; Gefen, Karahanna, \& Straub, 2003). Some other studies have discovered the importance of perceived usefulness on intentions and attitudes (Davis et al., 1989; Venkatesh, 2000; Pikkarainen, Karjaluoto, \& Pahnila, 2004). However, an investigation by Li (2014) contends that perceived usefulness is deluding and pointless in a gamification context. But a recent study was done by Yang et al. (2017) examined the context of marketing related to gamification and they maintained that gamification is a useful mechanism that brand managers can apply to improve consumers' brand attitude. They also claimed that the relationship among both brand and games is probably going to make a useful branding mechanism. And arguing about how the consumers perceived the game such as those who see the game useful in the acknowledgment/familiarity of the brand are probable to participate in the gamified procedure. Therefore, it is proposed that:

Hypothesis 1: Perceived usefulness positively affects customers' purchase intention.

Marketing activities such as advertisement, which attract customers to be engaged with gamified activities, have proven to be useful tools for increasing brand awareness, changing customers' brand attitude, and ultimately, influencing customer intention to purchase (MacKenzie, Lutz, \& Belch, 1986; Chang \& Tsai, 2007). The perceived usefulness of the gamification marketing process can as well influence customers' 
attitudes toward the brand. Biehal, Stephens, and Curio (1992), Sallam and Algammash (2016) stated that there are two basic determinants of predicting people's attitudes toward a new system or technology and perceived usefulness is one of them. They have also said that people's attitudes toward advertising are firmly associated to people's attitudes toward the brand. Therefore, it is suggested that:

Hypothesis 2: Perceived usefulness positively affects customers' brand attitude.

\subsection{Perceived Ease of Use}

In TAM, perceived ease-of-use is a necessary determinant for the acceptance of a given technology. Perceived ease-of-use (PEOU) was identified by Davis (1989) as the degree to which a person thinks that the use of a particular system does not require any effort. Davis, (1989) and Adams et al. (1992) said that perceived ease of use has a direct effect on both perceived usefulness and technology usage. According to Davis (1989), the combination of perceived ease of use and perceived usefulness causes the user's attitude and intention to embrace a specific information system. Van der Heijden (2003) added also that perceived ease of use has a significant effect on perceived usefulness, perceived enjoyment tend intention to take the use of a particular information system. Also, Davis, Bagozzi, and Warshaw (1989) have claimed that improving ease-of-use can as well be essential and helping to improve performance. Generally, if a system is easy to use then it is considered to be more useful. Venkatesh and Davis (2000) said that to the extent where the growth of ease of use leads to improved and better performance, it would have a direct effect on perceived usefulness. Like for example in some studies done by Kim et al. (2008), Lee et al. (2005), Morosan (2012), Ayeh (2015), Agag and El-Masry (2016), provide experimental support for a positive relationship between perceived usefulness and ease of use. Rodrigues, Oliveira and Costa (2016) described the ease of use in their research as the amplitude to which consumers may adopt gamified business applications, concluding that the consumers perceived it as effortless and easy. Therefore, it is proposed that:

Hypothesis 3: Perceived ease of use positively affects the perceived usefulness.

In previous researches, it has been found that in information technology adoption the perceived ease of use can influence behavior or attitude (e.g. Hsu \& Lu, 2004; Rodrigues, Costa, \& Oliveira, 2013). However, Benbasat and Barki (2007) and $\mathrm{Li}$ (2014) stated that ease of use was not appropriate in a gamification context. Yang et al. (2017) stated that a growing number of organizations are using gamification as a technology platform to influence the attitudes and behaviors of their consumers and adding that the accessibility level, simplicity, and degree of ease of understanding and interaction of these games vary. Perceived ease of use indicates the need for no effort to adopt a new technology or system (Davis et al., 1989). People tend to feel more pleased and more inclined to embrace the new technology or system if this technology is easy to use, thereby a positive impression will be created for this new system or technology. In this perspective, greater perceived ease of use is probably to provoke a more favorable attitude of the brand. A study in Malaysia of smartphone brands has discovered that there is a positive and significant relationship between customer satisfaction and brand attitude (Ghorban, 2012). Satisfaction was considered to be able to influence attitudes towards a system or use of technology (Tu, Fang, \& Lin, 2010). It was also discovered that the perceived ease of use had a significant influence on customer satisfaction. It is therefore rational to imply that the perceived ease of use is related to brand attitude. By considering the discussion above it is proposed that:

Hypothesis 4: Perceived ease of use positively affects customers' brand attitude.

\subsection{Perceived Social Influence}

Social influence is usually seen as a major factor to cause a change of attitude and also known as a significant motivation for game players, it is defined as the change in behavior, thoughts, feelings or attitudes that one person or a group provokes in another, intentionally or unintentionally, as a consequence of the way in which the changing person views his relationship with the influential party and society in a general. In the social media environment, the change of attitude is seen as an omnipresent influence on judgments. In marketing, parents, couples, mass media, school and purchasing skills represent several socio-cultural forces where they can have a major influence on the process of socializing the clientele (Gunter \& Furnham, 1998). 
The significance of social influence on brand attitudes and purchasing decisions of the younger generation is maintained by Kamaruddin and Mokhlis (2003). In the game process, people can frequently team up with other people or compete with them and thereby perceive social influence. In the context of gamified marketing, perceived social influence is known to have the ability to influence people's attitudes toward the new system and to further influence the brand's attitude towards people. Thus, the fifth hypothesis is postulated as below:

Hypothesis 5: Perceived social influence positively affects customers' brand attitude.

\subsection{Perceived Enjoyment}

According to Davis, Bagozzi and Warshaw (1992) perceived enjoyment (PEN) is defined as the degree to which the activity of using the technology is perceived as pleasant in itself aside from any performance consequences that can be anticipated (Teo \& Noyes, 2011). The enjoyment is considered as a major source of importance value for gamers, and therefore the players become more ready to persist in behavior with aspects of enjoyment (Deci et al., 1999). However, to the best knowledge of the authors, the impact of enjoyment on brand attitude still has not been evaluated yet in the gamification context. Taylor, Lewin, and Strutton (2011) suggested through one of their studies that users of social networking service (SNS) expectations from the entertaining advertisements is to have a positive influence on their attitude toward advertising on these SNS. Brackett and Carr (2001), Gao and Koufaris (2006) also supported this view, arguing that perceived enjoyment has been identified as one of the key influences on consumer attitude toward advertising in e-commerce. In a study of student acceptance of an internet-based learning medium, Lee et al. (2005) discovered that enjoyment not only directly influences behavioral intent but also indirectly influences it through attitude. And the sixth hypothesis is proposed as follows:

Hypothesis 6: Perceived enjoyment positively affect customers' brand attitude.

An intrinsic motivation variable such as perceived enjoyment is supposed to improve perceptions of extrinsic motivation such as perceived usefulness. Kubaş et al. (2016) study has shown that perceived enjoyment, perceived usefulness and perceived ease of use affect directly and positively each other. Other studies have shown that enjoyment has a positive effect on the usefulness of user-accepting systems and technologies such as e-learning systems (Yi \& Hwang, 2003), instant messaging (Li et al., 2005), and search engines (Liaw \& Huang, 2003). Wen et al. (2008) said that people who have a pleasant perception of the enjoyment of using the product are more likely to perceive it as useful. Also, Agarwal and Karahanna (2000) found a multidimensional construct called "cognitive absorption" which is a state of involvement with the software that had a significant influence on the perceived usefulness. A high cognitive absorption status that has a big impact on the perceived usefulness is enjoyment. Assuming all things are equal, the more enjoyable a product is, the more useful a product can be perceived. Davis et al. (1992) had found that usefulness and enjoyment were significant determinants of behavioral intention. The seventh hypothesis is hypothesized as follows:

Hypothesis 7: Perceived enjoyment positively affects the perceived usefulness.

\subsection{Trust}

Trust in brands is considered essential in many studies (Moorman et al., 1992; Doney \& Cannon, 1997). It is conceptualized as a significant factor in the company's success (Morgan \& Hunt, 1994). Brand trust is defined by Chaudhuri and Holbrook (2001) as "the willingness of the average consumer to rely on the ability of the brand to perform its stated function". As Doney and Cannon (1997) said that customer trust in the brand leads him or her to purchase intention or behavior, which is believed as a relationship market where the implications for trust evolution and maintenance is at the heart of the brand. It can be interpreted that trust is a key driver of purchase intention and behavior since it builds a precious transactional relationship. In such a context, purchase intention or behavior is not exclusively centered on just purchasing, but in an internal position or behavior concerning the brand, it can not constitute a sufficient basis for a complete understanding of the relationship brand-customer. Chaudhuri and Holbrook (2001) stated that 
purchasing intention behavior emphasizes the ongoing process and the maintenance of valuable and important relationships created born of trust. The main goal of marketing is to generate an intense relationship between customers and the brand, and the main foundation of this relationship is trust. Basing on this idea, Delgado et al. (2005) hypothesized that the emergence of trust in a brand affects buying intention and behavior as an expression of successful customer-brand relationships. The eighth hypothesis is developed as follows:

Hypothesis 8: Trust positively affects customers' purchase intention.

Chircu et al. (2000), Dahlberg et al. (2003), Pavlou (2003), and Ha and Stoel (2009) found strong correlations between perceived trust and perceived usefulness. In a study that they have done on customers' intentions to use online banking by using TAM, Chau et al. (2006) include the confidence factor into the model. As a result, the study concluded that the trust factor had a direct effect on perceived usefulness. And here is the ninth hypothesis is developed as follows:

Hypothesis 9: Trust positively affects the perceived usefulness.

\subsection{Attitude}

Eagly and Chaiken (2007) defined the attitude as a psychological path to evaluate a particular object with favor or disfavor. Attitudes can be predictive of behavior, because when an individual structure a positive or negative attitude towards specific objects, the probability of acting relies on that attitude. Besides, when a positive attitude is developed by consumers towards a product, it will have a positive effect on future purchase intention and actual buying behavior (Fazio, 1990). The more positive the attitude toward behavior, the greater is the intention of the individual to perform the behavior under study (Tarkiainen \& Sundqvist, 2005). Chen (2007) specified that consumer preferences and attitudes towards purchasing a specific product were based on their attitude and personal desire to perform a behavior. According to Engel and Blackwell (1978), purchase intention plays an important role as a predictor of consumer behavior, which is often used instead of actual behavior. The tenth hypothesis is developed as follows:

Hypothesis 10: Customers' attitude toward the brand positively affect consumers' purchase intention.

\section{Research Methodology}

\subsection{The Aim of The Study}

The aim of this study is to investigate the effect of gamification on customer purchase intention and also understand how it influences consumers' attitudes toward FMCG. This study results help future FMCG businesses to have a better understanding of the factors that affect their customers' attitudes toward their brands and to utilize gamification marketing strategies that may expand and develop their businesses.

\subsection{Procedure}

The survey participants were invited to participate in a gamification activity which included an FMCG application (OREO: Twist, Lick, Dunk). The participants were first required to download that application from the app store to the mobile devices. Then, the participants were asked to try the game with friends and then fill the online questionnaire. A brief explanation on how the application works:

Oreo: Twist, Lick, Dunk is the official game of the famous brand of chocolate cookies. The game makes you twist, lick and dunk the Oreo virtual cookies. First, slide in the cookies to "twist" them. Second, swipe them again to "lick" them and combine them into one big cookie. And then, drag the big biscuit into the glass of milk for the "dunk". 


\subsection{Instrument Development}

In the questionnaire of the study 5-point (1 - strongly disagree, 2 - disagree), 3 -neutral, 4 - agree), 5 - strongly agree). Scale items were adapted from previous studies. The scale items for Perceived usefulness were adapted from Hsu and Lu (2004). Perceived ease of use items adapted from Van der Heijden, Verhagen, and Creemers (2003), Hsu and Lu (2004). The scale items for perceived social influence were derived from Hsu and Lu (2004). Perceived enjoyment items were adapted from Wu and Liu (2007) and Wakefield et al. (2011). Purchase intention items were derived from Dodds et al. (1991), Prendergast et al. (2010), Jalilvand and Samiei (2012), and Lu et al. (2014). The scale items for attitude were adapted from Yalcin, Erdogmus and Demir (2009), and Park (2009). Perceived trust items were adapted from Delgado-Ballester and AlemanMunuera (2001), Chaudhuri and Holbrook (2001), Hsieh and Hiang (2004), Dixon, Bridson, Evans, and Morrison (2005), Caceres and Paparoidamis (2007), and Song, Wang and Han (2019).

\subsection{Data Collection and Sample Size}

The data for this research was collected through an online survey and was developed through a selfadministered primary data. The online questionnaire empowered by Google forms was distributed in English and the majority of responses were from participants who have knowledge of the English language living in Turkey. The survey was distributed via WhatsApp and Facebook to various groups and Twitter was used as well. The first part of the questionnaire examined the basic characteristics of the participants including gender, age, professional status, internet usage, internet usage hours and mobile operating system. All of them were examined with single-choice questions. This study used a non-probability convenience sampling method for data collection. According to Smith and Albaum, (2005), this method is based on the researcher's judgments and does not involve any probabilities techniques. Pallant (2013) recommended using the following formula proposed by Tabachnick and Fidell (2007), for the multiple regression techniques which require a large sample size for generalization purposes: $N>50+8 m$ Where: $N=$ sample size $m=$ the number of independent variables. Based on this formula required sample size for current research is $N>82$ (number of independent variables equals four). On the other hand, as stated by Hoelter's index, the SEM method should exceed 200 for a sufficient size because it represents the data inadequate way (Byrne, 2010). Therefore, the present study attempted to receive at least 200 responses to meet both of the abovementioned requirements. Even though young people are more likely to use game like applications, this study not only collected data from younger people but also from older age group people for the sake of generalization of the study results.

\subsection{Statistical Techniques}

The statistical techniques that were applied to current research are the Confirmatory Factor Analysis (CFA) and Structural Equational Model (SEM). Thanks to CFA the relationship between factors and their observed variable can be measured by Byrne (2010). At the same time, CFA is able to evaluate the validity of the measures while SEM allows theories to be tested quantitatively and it depends on the error factor. The main difference between CFA and SEM is the fact that CFA focuses on the relationship between the latent and observed variables, while SEM covers the structural path between the focusing (latent) variables. According to Harrington (2009), CFA is able to stand out as a unique analysis and considerate to be a part of SEM. IBM SPSS version 25 and IBM SPSS AMOS version 21 statistical software were used to conduct the analysis for this research.

\section{Data Analysis}

\subsection{Demographics of The Respondents}

The current study sample consisted of 200 complete responses. $42.5 \%$ of the respondents were male and $57.5 \%$ of the respondents were female. The age of survey participants varied between 17 and 70 years. The majority percentage of the profession relates to student with $48 \%$. Also, majority of the respondents (72.5\%) use Internet every day. For the internet usage hours, the majority of responses have chosen" more 
than 4 hours a day" with (43.5\%), followed by $31.5 \%$ for "3-4hours". $77 \%$ of the respondents chose to use Android as mobile operating system.

Table 1. Demographic Profile of Respondents

\begin{tabular}{|c|c|c|c|}
\hline Demographics & & $\mathbf{N}$ & $\%$ \\
\hline \multirow{3}{*}{ Gender } & Male & 85 & 42.5 \\
\hline & Female & 115 & 57.5 \\
\hline & Total & 200 & 100 \\
\hline \multirow{8}{*}{ Age } & 17 or less & 29 & 14.5 \\
\hline & 18 to 24 & 52 & 26 \\
\hline & 25 to 34 & 54 & 27 \\
\hline & 35 to 44 & 32 & 16 \\
\hline & 45 to 54 & 16 & 8 \\
\hline & 55 to 64 & 6 & 3 \\
\hline & 65-above & 11 & 5.5 \\
\hline & Total & 200 & 100 \\
\hline \multirow{6}{*}{ Professional Status } & Student & 96 & 48 \\
\hline & Employer & 26 & 13 \\
\hline & Employee & 57 & 28.5 \\
\hline & Retired & 11 & 5.5 \\
\hline & Unemployed & 10 & 5 \\
\hline & Total & 200 & 100 \\
\hline \multirow{6}{*}{ Internet Usage } & Everyday & 145 & 72.5 \\
\hline & More than once a day & 40 & 20 \\
\hline & Once a day & 11 & 5.5 \\
\hline & Once a month & 1 & 0.5 \\
\hline & Less than once a month & 3 & 1.5 \\
\hline & Total & 200 & 100 \\
\hline \multirow{6}{*}{ Internet Usage Hours } & Less than 1 hour a day & 4 & 2 \\
\hline & 1-2 hours & 10 & 5 \\
\hline & 2-3 hours & 36 & 18 \\
\hline & 3-4 hours & 63 & 31.5 \\
\hline & More than 4 hours a day & 87 & 43.5 \\
\hline & Total & 200 & 100 \\
\hline \multirow{4}{*}{$\begin{array}{l}\text { Mobile Operating } \\
\text { System }\end{array}$} & Android & 155 & 77.5 \\
\hline & IOS & 33 & 16.5 \\
\hline & Other & 12 & 6 \\
\hline & Total & 200 & 100 \\
\hline
\end{tabular}

\subsection{Normality Assessment}

Multivariate normality is one of the main assumptions of SEM analysis. In this study kurtosis and skew statistics were taken into consideration to assess the normality of the data. Skew is defined as a statistical measure measuring the asymmetry of distribution data from the mean (Kline, 2011). Kurtosis, on the other hand, is a statistical measure that, for positive kurtosis, refers to data that has a heavy-tailed with a higher peak, while negative kurtosis represents data that has a clear tailed with a lower peak compared to a normal distribution. The distribution with positive kurtosis in the description is called leptokurtic and the distribution with negative kurtosis is called platykurtic (Kline, 2011). In this study, for each item skew and kurtosis statistics were obtained by using AMOS software. West et al. (1995) proposed a reference of substantial departure from normality as an absolute skew value $>2$ and absolute kurtosis value $>7$. In addition, when absolute values of Skewness Index $>3.0$ the data distribution is considered as extremely skewed (Kline, 2011) and when absolute values of kurtosis Index > 8.0 the data distribution depicts "extreme" 
kurtosis (Kline, 2011). In this study, kurtosis and skew statistics were found to be within the recommended thresholds of West et al. (1995) and (Kline, 2011), and therefore it can be concluded that study data do not violate the normality assumption.

\subsection{Multicollinearity Assessment}

In a statistical model, multicollinearity presents a phenomenon in which strong intercorrelations exist between independent variables. Serious problems that can be caused by multicollinearity if a simple correlation between independent variables like predictor or regressor exceeds 0.8 or 0.9 (Judge et al., 1982; Katz, 2006). In Table 2 below the Correlation between model factors is given. The correlation between model factors is given in Table 2. Independent variables of this study are Perceived_EOU, perceived enjoyment, Social_Influence, and Trust. The correlation between these four variables is far below the recommended threshold of 0.8 . Therefore, multicollinearity is not considered a concern in this study.

Table 2. Correlations Between Factors

\begin{tabular}{|ll|l|}
\hline Perceived_EOU $<-->$ & Social_Influence & 0.558 \\
Perceived_EOU $<-->$ & Perceived_Enjoyment & 0.705 \\
Perceived_EOU $<-->$ & Trust & 0.504 \\
Social_Influence $<-->$ & Perceived_Enjoyment & 0.507 \\
Social_Influence $<-->$ & Trust & 0.588 \\
Perceived_EOU <--> & Trust & 0.679 \\
\hline
\end{tabular}

\subsection{Validity and Reliability Assessment}

One of the most important elements of quantitative research is validity and reliability that mainly focus on measurement aspects. Validity consists of checking whether the variables are accurately measured. Generally, the validity can be evaluated in several forms: Construct validity, Content validity, Criterion validity (Hamed Taherdoost, 2016). This study concentrates on construct validation, focusing particularly on: Convergent validity. Reliability assessment is the second method of evaluating the quality of the measuring. It examines the consistency of the element measured among respondents and the stability of characteristics over a given period of time (Smith \& Albaum, 2005).

The thresholds proposed by Gefen and Straub (2005), Hair et al. (2010) to evaluate validity and reliability are as follows. To ensure reliability: CR (Composite Reliability) $>0.7$ and to ensure Convergent: AVE (Average Variance Extracted) $>0.5$

To conduct a CFA, it is important to ensure reliability and convergent validity. Table 2 represent the results of validity and reliability assessment conducted for this research. It was executed based on Correlations and Standardized Regression Weights tables pulled back with an assistance of Amos software. Convergent validity has been established and proven by an AVE greater than 0.5 . Reliability has also been established and certified by a CR greater than 0 .

Table 3. Resume of Validity and Reliability Assessment

\begin{tabular}{|l|c|c|}
\hline & CR & AVE \\
\hline TR & 0.841 & 0.570 \\
\hline PE & 0.821 & 0.511 \\
\hline PI & 0.842 & 0.641 \\
\hline ATT & 0.873 & 0.632 \\
\hline SI & 0.840 & 0.638 \\
\hline PU & 0.884 & 0.718 \\
\hline PEOU & 0.897 & 0.685 \\
\hline
\end{tabular}


The composite reliability (CR) values of all variables, Perceived Usefulness (PU), Perceived Ease of Use (PEOU), Perceived Enjoyment (PE), Social Influence (SI), Trust (TR), Attitude (ATT) and Purchase Intention $(\mathrm{PI})$ are $0.884,0.897,0.821,0.840,0.841,0.873$ and 0.842 respectively. This means that $\mathrm{CR}$ of all these variables is greater than the threshold value of 0.7 , hence their $C R$ is acceptable.

The Average Variance Extracted (AVE) values of all variables, PU, PEOU, PE, SI, TR, ATT and PI are $0.718,0.685,0.511,0.638,0.570,0.632$ and 0.641 respectively. AVE of all these variables is acceptable and convergent validity holds as the values are greater than the threshold value of 0.5 .

\subsection{Confirmatory Factor Analysis (CFA)}

Confirmatory factor analysis (CFA) is a multivariate statistical procedure. It is a special form of factor analysis that verifies the compatibility of measurements with the nature of the construction in question. For this study, confirmatory factor analysis (CFA) was performed in SPSS AMOS version 21.

As Hooper et al. (2008) said there are three types of model fit indices that can be considered by researchers:

- Incremental fit indices (CFI and NFI)

- Absolute fit indices ( $\mathrm{X} 2 / \mathrm{df}, \mathrm{RMSEA}, \mathrm{SRMR}, \mathrm{GFI}$ and AGFI)

- Parsimony fit indices (PGFI and PNFI; AIC and CAIC)

- The recommended thresholds that will help determine the fit goodness are:

- $\mathrm{CFI} \geq 0.95$ (Hu \& Bentler, 1999; Schreiber et al., 2006).

- p-value $>0.05$ (Hooper, Coughlan \& Mullen, 2008).

- $\mathrm{AGFI}>$ the values close to 1.00 demonstrates good level of fit (Byrne, 2010).

- GFI - the values close to 1.00 demonstrate good level of fit (Byrne, 2010).

- RMSEA - the values between 0 and 0.08 (Hooper, Coughlan \& Mullen, 2008) or $\leq 0.06$ to 0.08 (Schreiber et al., 2006) demonstrate good level of fit.

- $\mathrm{SRMR} \leq 0.05$ (Byrne, 2010) or $\leq 0.08$ (Schreiber et al., 2006).

- PCLOSE > 0.05 (Byrne, 2010).

While conducting CFA (Figure2) analysis there were 351 distinct sample moments identified which refers to the number of elements available in sample covariance matrix. 75 parameters were estimated which is leaving 276 degrees of freedom. With Chi-square value of 539,532 the probability level equivalents to 0.000 . Having $\chi 2 / \mathrm{df}=1.955 ; \mathrm{RMSEA}=0.067 ; \mathrm{PCLOSE}=0.000 ; \mathrm{SRMR}=0.047 ; \mathrm{GFI}=0.838 ; \mathrm{AGFI}=0.794 ; \mathrm{CFI}=$ 0.926 demonstrates good fit according to collected data within this study (Table 5).

While the measurement model (i.e., CFA) checks the relationship between the latent variables and their measures. The structural Equation Modeling focuses on analyzing and evaluating the relationships among the latent variables of the proposed model. Moreover, comparing SEM to CFA, SEM extends the probability of the relationship between the latent variables and envelops two parts: Measurements model (basically the CFA) and Structural model.

To examine hypotheses, global (model fit and R-squared) and local ( $p$-value) tests been conducted through Structural Equation Modeling (Figure 3). Model fit statistical results conducted for structural equation model had following results (Table 6). The obtained results refer to goodness-of-fit. 
Figure 2. Confirmatory Factor Analysis

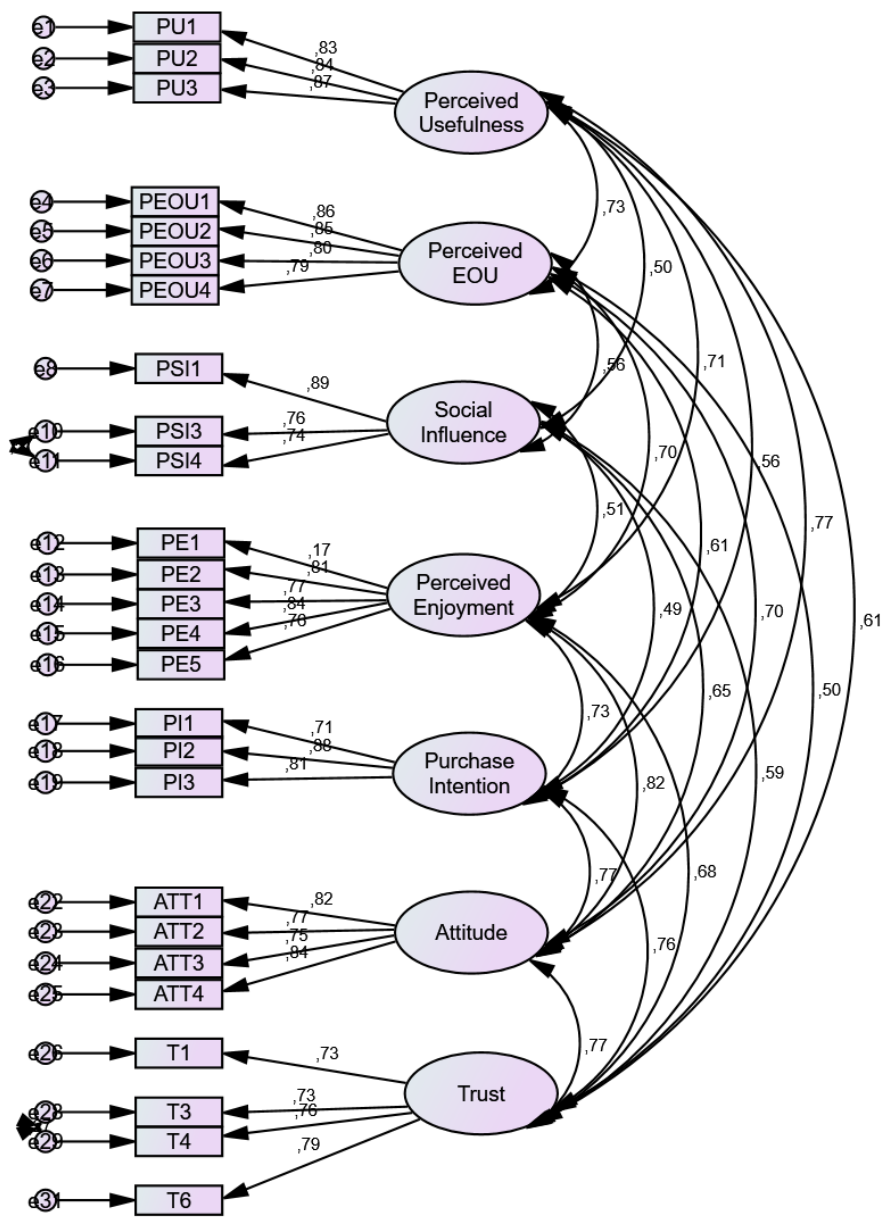

Table 4. Model Fit Analysis for CFA

\begin{tabular}{|c|c|c|}
\hline Measure & Thresholds & Proposed Model Results \\
\hline Chi-square (CMIN) & & 539.53 \\
\hline CMIN/DF & $<3$ good; $<5$ permissible & 1.955 \\
\hline P-value & & 0.000 \\
\hline CFI & $\begin{array}{c}0.95>\text { (great), } 0.90> \\
\text { (traditional), } 0.80> \\
\text { sometimes permissible }\end{array}$ & 0.926 \\
\hline GFI & $0.95>$ & 0.838 \\
\hline AGFI & $0.80>$ & 0.794 \\
\hline SRMR & $0.09<$ & 0.067 \\
\hline RMSEA & $\begin{array}{c}0.05<\mathrm{i} \text { (good), } 0.05<\mathrm{x} \\
<0.10 \text { (moderate), } \mathrm{x}> \\
0.10 \text { (bad) }\end{array}$ & 0.069 \\
\hline PCLOSE & $>0.05$ & 0.000 \\
\hline
\end{tabular}


Table 5. Model Fit Statistical for SEM

\begin{tabular}{|c|c|}
\hline Measure & Result \\
\hline Chi-square (CMIN) & 558.785 \\
\hline CMIN/DF & 1.989 \\
\hline P-value & 0.000 \\
\hline CFI & 0.921 \\
\hline GFI & 0.835 \\
\hline AGFI & 0.794 \\
\hline SRMR & 0.070 \\
\hline RMSEA & 0.070 \\
\hline PCLOSE & 0.000 \\
\hline
\end{tabular}

Figure 3. Structural Equation Model

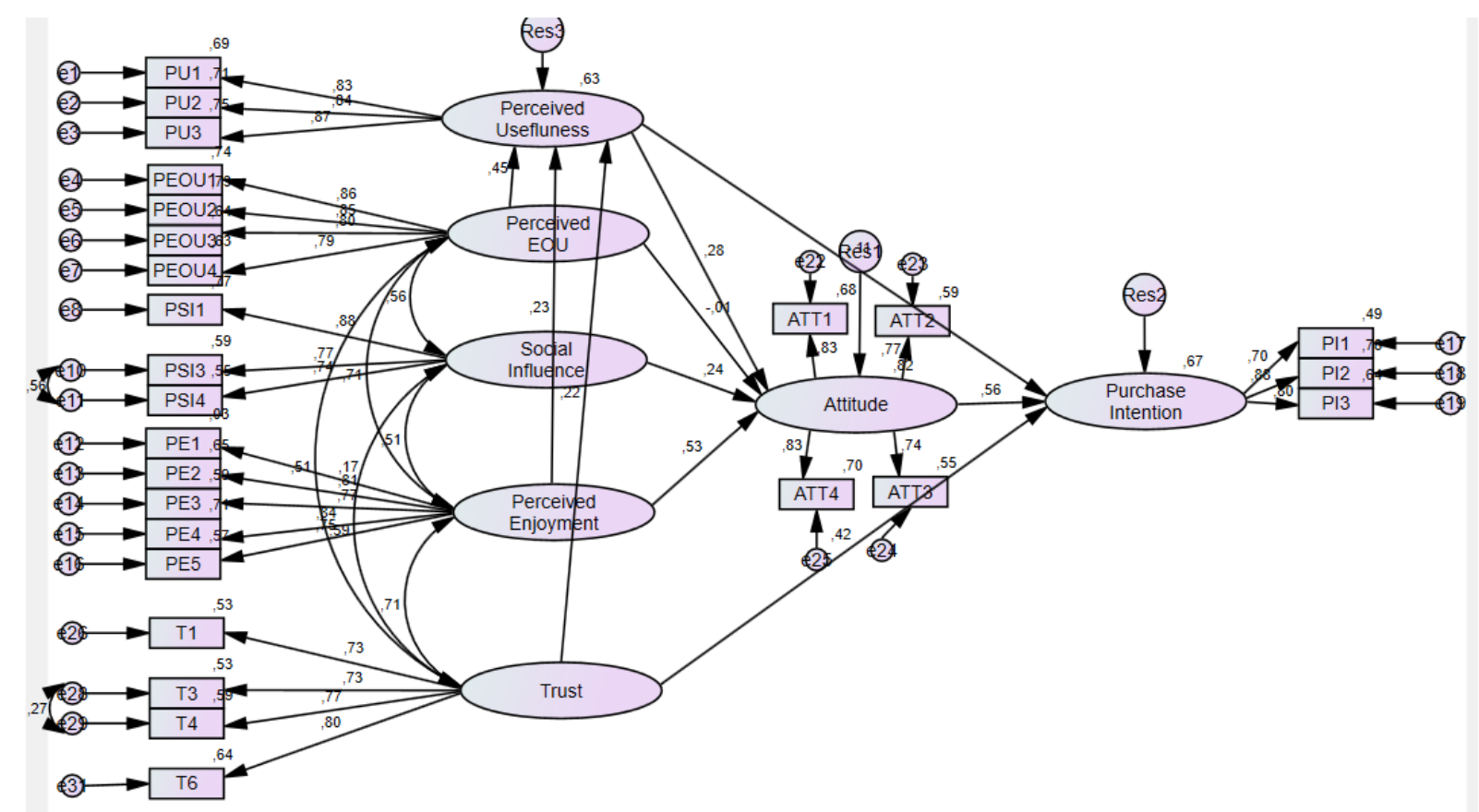

Byrne (2010) defined R-squared and also known by the name of Squared Multiple Correlations (SMC) as an indicator of the level of variance (percentage) that predictors of the factors in question reflect. Having minimum value of 0.028 and maximum of 0.816 in SMC analysis it can be concluded that in general predictors explain respective variable relatively well.

Results of the hypotheses testing are summarized below.

- Perceived Usefulness is not related to Purchase Intention thus Perceived Usefulness does not affect customers' purchase Intention ( $H 1$ : $ß=-0.115, S . E .=0.105$ and $p$-value $=0.273$ ).

$\mathrm{H}_{1}$ : Perceived Usefulness positively affects customers' purchase intention = Not Supported

- Perceived Usefulness is positively related to Attitude thus Perceived Usefulness positively affects customers' brand attitude (Attitude) ( $\mathrm{H} 2$ : $\beta=0.275, \mathrm{~S} . \mathrm{E} .=0.086$ and $\mathrm{p}$-value $=0.001$ ).

$\mathrm{H}_{2}$ : Perceived Usefulness positively affects customers' brand attitude $=$ Supported 
- Perceived Ease of Use is positively related to Perceived Usefulness thus Perceived Ease of Use positively affects the perceived usefulness (H3: $ß=0.475$, S.E. $=0.094$ and $p<0.001$ ).

$\mathrm{H}_{3}$ : Perceived Ease of Use positively affects the perceived usefulness $=$ Supported

- Perceived Ease of Use is not related to Attitude thus Perceived Ease of Use does not affect customers' brand attitude (Attitude) (H4: $ß=-0.005$, S.E. $=0.089$ and $p$-value= 0.952 ).

$\mathrm{H}_{4}$ : Perceived Ease of Use positively affects customers' brand attitude $=$ Not Supported

- Perceived Social Influence is positively related to Attitude thus Perceived Social Influence positively affects customers' brand attitude (Attitude) (H5: $ß=0.177$, S.E. $=0.047$ and $p<0.001$ ).

$\mathrm{H}_{5}$ : Perceived Social Influence positively affects customers' brand attitude = Supported

- Perceived Enjoyment is positively related to Attitude thus Perceived Enjoyment positively affects customers' brand attitude (Attitude) (H6: $\beta=0.897$, S.E. $=0.419$ and $p$-value $=0.032$ ).

$\mathrm{H}_{6}$ : Perceived Enjoyment positively affect customers' brand attitude= Supported

- Perceived Enjoyment is not related to Perceived Usefulness thus Perceived enjoyment does not affect the perceived usefulness (H7: $ß=0.391$, S.E. 0.258 and $p$-value $=0.129$ ).

$\mathrm{H}_{7}$ : Perceived enjoyment positively affects the perceived usefulness $=$ Not Supported

- Trust is positively related to purchase intention thus Trust positively affects customers' purchase intention (H8: $\beta=0.550$, S.E. $=0.131$ and $p<0.001$ ).

$\mathrm{H}_{8}$ : Trust positively affects customers' purchase intention= Supported

- Trust is positively related to perceived usefulness thus Trust positively affects the perceived usefulness (H9: $ß=0.289$, S.E.= 0.120 and $p$-value $=0.016$ ).

$\mathrm{H}_{9}$ : Trust positively affects the perceived usefulness = Supported

- Attitude is positively related to purchase intention thus Attitude positively affects customers' purchase intention ( $H 10$ : $\beta=0.566$, S.E. $=0.128$ and $p<0.001$ ).

$\mathrm{H}_{10}$ : Customers' attitude toward the brand positively affects consumers' purchase intention= Supported The summary of the hypotheses testing is provided in Table 6.

Table 6. Hypotheses Testing Results

\begin{tabular}{|c|c|c|}
\hline Hypotheses & Relationships & Status \\
\hline $\mathrm{H} 1$ & $\mathrm{PI} \leftarrow \mathrm{PU}$ & Not Supported \\
\hline $\mathrm{H} 2$ & $\mathrm{ATT} \leftarrow \mathrm{PU}$ & Supported \\
\hline $\mathrm{H} 3$ & $\mathrm{PU} \leftarrow \mathrm{PEOU}$ & Supported \\
\hline $\mathrm{H} 4$ & $\mathrm{ATT} \leftarrow \mathrm{PEOU}$ & Not Supported \\
\hline $\mathrm{H} 5$ & $\mathrm{ATT} \leftarrow \mathrm{SI}$ & Supported \\
\hline $\mathrm{H} 6$ & $\mathrm{ATT} \leftarrow \mathrm{PE}$ & Supported \\
\hline $\mathrm{H} 7$ & $\mathrm{PU} \leftarrow \mathrm{PE}$ & Not Supported \\
\hline $\mathrm{H} 8$ & $\mathrm{PI} \leftarrow \mathrm{TR}$ & Supported \\
\hline $\mathrm{H} 9$ & $\mathrm{PU} \leftarrow \mathrm{TR}$ & Supported \\
\hline $\mathrm{H} 10$ & $\mathrm{PI} \leftarrow \mathrm{ATT}$ & Supported \\
\hline
\end{tabular}




\section{Discussion and Conclusion}

Taking into account the current trend of gamification and its great growth potential in marketing market and its growth in influencing and engaging more customers in different fields by using game-like strategies, this thesis focused on the influence of gamification on consumers' attitude and intention to purchase fast-moving consumer goods, especially consumers living in Turkey.

Gamification is recently considered as very important tool for both business and consumers, as it helps to make the interaction with customers more entertaining and fun which lead to gain new customers; and it also helps customers to have a better and enjoyable experience by introducing their product in a fun way which helps them to be more familiar with the product. Many gamification resolutions in this regard have been revealed on the basis of a literature review conducted in this context. This study also investigates the influence of the factors of gamification on consumers' attitude and purchase intention; among these factors, Attitude is considered as a mediator variable. Moreover, understanding the effects of such influencing factors is important and can be beneficial for both the marketing business industry as well as an academic field. This study introduces the six factors perceived model to better understand the influence of gamification on consumers' attitude and this investigation expands the TAM.

Primary data has been obtained for analysis of research questions and hypotheses testing purposes. In total there were 200 volunteer participants of the survey. The impacts of gamification features were analyzed through CFA and SEM analysis. Within the scope of CFA, the model fit of hypothesized model has been tested. $\chi 2 / d f$, RMSEA, SRMR, CFI, PCLOSE, GFI and AGFI. The results revealed a well fit model. SEM analysis covered hypotheses testing that included both global and local tests. The assessment of model fit showed a good fit and based on a squared $R$ analysis it was concluded that the predictors explain the respective variable relatively well. After the global test, the local test was performed in terms of analyzing the $p$-value. According to the summary of hypotheses testing, seven of the proposed hypotheses were statistically and significantly supported and three was unsupported. Perceived usefulness is the first factor of gamification and has a significant direct influence on customers 'brand attitude. According to previous work such as Soroa-Koury and Yang (2010), Hosseini, Alakbarli, Ghabili, Shoja, and Hakim (2011) reports that perceived usefulness positively influence brand attitudes. The current study, therefore, confirm their work through results finding that support these studies by finding a positive relationship between perceived usefulness and attitude with $p$-value $<0.5$. But unfortunately, the relationship between perceived usefulness and purchase intention was not found to be significantly. The finding of these two relationships got a $p>0.10$ which indicated that perceived usefulness does not positively affect customers 'purchase intention. This result coherent with the theory of Davis (1989), where it has been found that not all TAM components, influence purchase intention such as perceived usefulness here.

The second factor, perceived ease of use does not positively relate to attitude which also confirms the work of previous studies of Soroa-Koury and Yang (2010) and Hosseini et al. (2011). The result of the current finding regarding this factor is $p>0.05$ and with such result it can be claimed that perceived ease of use does not positively affects customers' brand attitude. However, there is positive relationship between perceived ease of use and perceived usefulness with $p$-value $<0.05$ which leads to conclude that perceived ease of use positively affects the perceived usefulness. In the case of Perceived enjoyment, it was proved to be a strong predictor for the brand's attitude in the process of gamification, and it was found to significantly impact brand attitude in the gamification process for marketing purposes with a $p$-value $p<0.05$. This is in line with the advergame study that Wise, Bolls, Kim, Venkataraman, and Meyer (2008) studied and pointed out that game enjoyment affects remarkably the brand attitude. But on the other hand, perceived Enjoyment is not positively related to perceived usefulness with a $p$-value $>0.10$ thus perceived enjoyment does not positively affect the perceived usefulness. Perceived social influence is the fourth factor of gamification and has also a significant direct influence on customers' brand attitude in the context of gamified marketing. The result reveals a positive relationship between perceived social influence and attitude with $p$-value $<0.5$. This study consistent with Hamari and Koivisto (2013) who indicated that social aspects play a major role in gamification specifically like playing games and perceived that social factors like social influence contribute to the use of intentions and attitudes toward gamification services. Trust is the fifth factor of gamification 
and has also significant direct influence on customers' purchase intention. The result reveals a positive relationship between trust and purchase intention with $p$-value $<0.5$. This finding claims that trust positively affects customers 'purchase intention. And another positive relationship between trust and perceived usefulness with $p<0.05$ thus Trust positively affects the perceived usefulness. The result of the attitude revealed that the hypothesis between consumer attitude and purchase intention is accepted with high significance with a $p<0.5$, and according to previous studies of Ajzen (1991), Malhotra and Galletta (1999), Chen (2007), and Hartman and Ibanez (2012) attitude positively affects intention and for those who have positive attitudes toward a particular behavior, will carry out that specific behavior instead of others.

\subsection{Implication}

The results of this study provide several theoretical implications that add to the literature in many influential ways, especially to the marketing literature, it contributes by supplying an expansion to the model of TAM model used by marketers in the context of gamification. Following previous researches, the findings affirmed that TAM is a legitimate theory not only in the context of the adoption of an information system but including as well in the evaluation of a marketing system. Moreover, in light of the expanded model, through this examination some positive and beneficial effects of gamification in FMCG have been revealed for marketing purpose. It is in this context that certain players in the FMCG sector, which is a very important market and which influences most of our daily activities are turning more and more towards gamification by adopting original and innovative methods based on the game to entertain potential buyers and encourage them to buy their products and thus create a loyal clientele. The entertainment and fun that perceived enjoyment contributes to a gamified brand are likely to drive positive attitudes toward that brand and the research study highlights on the importance of enjoyment with attitude of consumer, however, getting that much fun and enjoying the gamified experience does not motivate the consumers enough to buy the product. It is more likely to make them engaged with that brand so in the future they can buy or be loyal to it. On the other hand, trust was considered to be very significant through this finding; consumers are ready to buy the product if it is related to their preferred brand. It also shows the importance of trust which helps to enhance the brand-consumer relationship. Therefore make the consumer have a strong belief and faith in the brand's future products and services that expected to meet their expectation. Game designers or marketers should focus more on components that can provide better fun experiences and enjoyable perceptions while playing the game or using the gamified application, especially taking into consideration consumers' opinions or expectations from a gamified FMCG platform. Indeed, the use of online games are quite addictive and provide mental stimulation and entertainment value for adults which can give amazing results for the brand by creating a certain familiarity with the brand's products. In addition, online games have to be fairly easy to play and keep people engaged longer compared to traditional banner ads. For instance, as in game design, the process of enjoyable components of gamification can be competition with other participants, engaging interaction, or the reward system. In addition, marketers need to focus more on how to win consumers' hearts and gain their trust. This will give the brand more chance for its product to be bought by the consumer and for its gamified platform to get more attention. Finally, examining the relationship between purchase intention with the process of gamification marketing and the attitude to a specific brand in that process can potentially allow marketers to increase the intention of participants when they perform marketing activities and also, in theory, fill the knowledge gap on the relationship between purchase intention and brand attitude.

\subsection{Limitations and Recommendations for Future Researches}

Primarily, this research tried to depict an understanding of the influence of Gamification features on consumers' attitudes toward purchasing intention. Despite the fact that the obtained results appear to be motivating a few limitations should be considered in this study. Firstly, the data that was used for analysis has been obtained based on the ease of accessibility. Secondly, despite the fact that respondents prior to filling in surveys were given detailed information about its purpose and objective, surveys carried selfreported nature. Thirdly, only five gamification features (based on collected literature within study scope) have been analyzed in the current study. There might other critical gamification features that impact the 
attitude of consumers living in turkey in a serious way. Also the acquired results probably won't be accessible and available after a certain period, and the model might require specific updates and adjustments later on. Finally, the limited time was another constraint that the researcher faced during the research period. By taking into consideration all of the above mentioned limitations, future researchers are recommended to carry out their studies by addressing these limitations in order to improve the generalizability of the study results.

\section{Disclosure Statements}

1. The authors of this article confirm that their work complies with the principles of research and publication ethics.

2. No potential conflict of interest was reported by the authors.

3. This article was screened for potential plagiarism using a plagiarism screening program.

\section{References}

Acar, A. (2007). Testing the effects of incidental advertising exposure in online gaming environments. Journal of Interactive Advertising, 8, 45-56.

Ajzen, I. (1991). The theory of planned behavior. Organizational Behavior and Human Decision Processes, 50(2), 179211.

Agag, G., \& El-Masry, A. A. (2016). Understanding consumer intention to participate in online travel community and effects on consumer intention to purchase travel online and WOM: An integration of innovation diffusion theory and TAM with trust. Computers in Human Behavior, 60, 97-111.

Albaum, M. (2005). Safety sells: Market forces and regulation in the development of airbags. Retrieved April 15, 2020 from https://www.iihs.org/media/186adabe-9ef4-479c-ad37-36b9f0e7fca1/KaOwWO/Albaum _Safety_Sells.pdf

Agarwal, R., \& Karahanna, E. (2000). Time flies when you're having fun: Cognitive absorption and beliefs about information technology usage. MIS Quarterly, 24(4), 665-694.

Ayeh, J. K. (2015). Travellers' acceptance of consumer-generated media: An integrated model of technology acceptance and source credibility theories. Computers in Human Behavior, 48, 173-180.

Benbasat, I., \& Barki, H. (2007). Quo Vadis TAM? Journal of the Association for Information Systems, 8(4), 212-218.

Bagozzi, R. P., \& Warshaw, P. R. (1992). An examination of the etiology of the attitude-behavior relation for goal-directed behaviors. Multivariate Behavioral Research, 27(4), 601-634.

Biehal, G., Stephens, D., \& Curlo, E. (1992). Attitude toward the ad and brand choice. Journal of Advertising, 11(3), 1936.

Byrne, B. M. (2010). Structural equation modeling with AMOS: Basic concepts, applications, and programming (2nd edition). New York: Routledge/Taylor \& Francis Group.

Caceres, R. C., \& Paparoidamis, N. G. (2007). Service quality, relationship satisfaction, trust, commitment and businessto-business loyalty. European Journal of Marketing, 41(7), 836-867.

Chang, E. H., Chung, R. S., \& Tsai, Y. H. (2007). Effect of different application rates of organic fertilizer on soil enzyme activity and microbial population. Soil Science and Plant Nutrition, 53, 132-140.

Chaudhuri, A., \& Holbrook, M. B. (2001). The chain of effects from brand trust and brand affect to brand performance: The role of brand loyalty. Journal of Marketing, 65(2), 81-93.

Chau, C. K, Yik, F. W. H, Hui, W. K., Lui, H. C., \& Yu, H. K. (2006). Environmental impacts of building materials and building services components for commercial buildings in Hong King. Journal of Cleaner Production, 15(18), 1840-1851

Chen, M. F. (2007). Consumer attitudes and purchase intentions in relation to organic foods in Taiwan: Moderating effects of food-related personality traits. Food Quality and Preference, 18(7), 1008-1021.

Chircu, A. M., \& Kauffman, R. J. (2000). Reintermediation strategies in business-to-business electronic commerce. International Journal of Electronic Commerce, 4(4), 7-42. 
Davis, F. D. (1989). Perceived usefulness, perceived ease of use, and user acceptance of information technology. MIS Quarterly, 13(3), 319-339

Davis, F. D., Bagozzi, R., \& Warshaw, P. (1989). User acceptance of computer technology: A comparison of two theoretical models. Management Science, 35(8), 982-1003.

Davis, F. D., Bagozzi, R. P., \& Warshaw, P. R. (1992). Extrinsic and intrinsic motivation to use computers in the workplace. Journal of Applied Social Psychology, 22(14), 1111-1132.

Dahlberg, P. (2003). Local mobility. Gothenburg studies in informatics Report, 27, Göteborg University. Retrieved April 15, 2020 from https://gupea.ub.gu.se/handle/2077/15846

Delgado-Ballester, E., \& Munuera-Alemán, J. L. (2001). Brand trust in the context of consumer loyalty. European Journal of Marketing, 35(11/12), 1238-1258.

Delgado, M. R., Frank, R. H., \& Phelps, E. A. (2005). Perceptions of moral character modulate the neural systems of reward during the trust game. Nature Neuroscience, 8(11), 1611-1618.

Deci, E. L., \& Ryan, R. M. (1985). The general causality orientations scale: Self-determination in personality. Journal of Research in Personality, 19(2), 109-134.

Deci, E. L., Koestelr, R., \& Ryan, R. M. (1999). A nieta-anualytic review of experiments examining the effects of extrinsic rewards on intrinsic motivation. Psychological Bulletin, 125, 627-668.

Harry, J. (2014). Gamification: Intrinsic motivation for lasting engagement. Retrieved from: https://elearningindustry.com/gamification-intrinsic-motivation-lasting-engagement

Deterding, S., Dixon, D., Khaled, R., \& Nacke, L. (2011, September). From game design elements to gamefulness: Defining "gamification". In Proceedings of the 15th international academic MindTrek conference: Envisioning future media environment, 9-15.

Deterding, S., Khaled, R., Nacke, L. E., \& Dixon, D. (2011). Gamification: Toward a definition. In CHI 2011 gamification workshop proceedings, 12-15. Vancouver BC, Canada.

Doney, P. M., \& Cannon, J. P. (1997). An examination of the nature of trust in buyer-seller relationships. Journal of Marketing, 61(2), 35-51.

Dodds, W. B., Monroe, K. B., \& Grewal, D. (1991). Effect of price, brand and store information on buyers' product evaluations. Journal of Marketing Research, 28(3), 307-319.

Dixon, J., Bridson, K., Evans, J., \& Morrison, M. (2005). An alternative perspective on relationships, loyalty and future store choice. The International Review of Retail, Distribution and Consumer Research, 15(4), 351-374.

Eagly, A. H., \& Chaiken, S. (2007). The advantages of an inclusive definition of attitude. Social cognition, 25(5), 582-602.

Engel, J. F., Blackwell, R. D., \& Kollat, D. T. (1978). Consumer behavior. New York: Dryden Press, Hinsdale, IL.

Fazio, R. H. (1990). Multiple processes by which attitudes guide behaviour: The MODE model as an integrative framework. In M. P. Zanna (Ed.), Advances in Experimental Social Psychology (23, 75-109). New York: Academic Press.

Fisbein, M., \& Ajzen, I. (1975). Belief, attitude, intention and behavior: An introduction to theory and research. Reading, MA: Addison-Wiley Publishing Company.

Fletcher, J. D., \& Tobias, S. (2006). Using computer games and simulations for instruction: A research review. In Proceedings of the Society for Advanced Learning Technology Meeting, Orlando, FL.

Gao, Y., \& Koufaris, M. (2006). Perceptual antecedents of user attitude in electronic commerce. ACM SIGMIS Database: the DATABASE for Advances in Information Systems, 37(2-3), 42-50.

Gefen, D., \& Straub, D. W. (2000). The relative importance of perceived ease-of-use in IS adoption: A study of ecommerce adoption. Journal of the Association for Information Systems, 1(8), 1-30.

Gefen, D., Karahanna, E., \& Straub, D. W. (2003). Trust and TAM in online shopping: An integrated model. MIS Quarterly, 27(1), 51-90.

Gefen, D., \& Straub, D. (2005). A practical guide to factorial validity using PLS-Graph: Tutorial and annotated example. Communications of the Association for Information systems, 16(1), 5.

Glotz, J. (2019). Game on: why FMCG is making a serious play for gaming and esports. Retrieved April 17, 2020 from https://www.thegrocer.co.uk/consumer-trends/game-on-why-fmcg-is-making-a-serious-play-for-gaming-andesports/594736.article

Ghorban, Z. S. (2012). Brand attitude, its antecedents and consequences. Investigation into smartphone brands in Malaysia. Journal of Business and Management, 2(3), 31-35. 
The Influence of Gamification on Online Consumers' Attitude and Intention to Purchase Fast Moving Consumer Goods

Gunter, B., \& Furnham, A. (1998). Children as consumers: A psychological analysis of the young people's market. London: Psychology Press.

Gronemus, J. Q., Hair, P. S., Crawford, K. B., Nyalwidhe, J. O., Cunnion, K. M., \& Krishna, N. K. (2010). Potent inhibition of the classical pathway of complement by a novel C1q-binding peptide derived from the human astrovirus coat protein. Molecular Immunology, 48(1-3), 305-313.

Grigorovici, D. M., \& Constantin, C. D. (2004). Experiencing interactive advertising beyond rich media: Impacts of ad type and presence on brand effectiveness in $3 \mathrm{D}$ gaming immersive virtual environments. Journal of Interactive Advertising, 5(1), 22-36.

Ha, S., \& Stoel, L. (2009). Consumer e-shopping acceptance: Antecedents in a technology acceptance model. Journal of Business Research, 62, 565-571.

Hamari, J. (2013). Transforming homo economicus into homo ludens: A field experiment on gamification in a utilitarian peer-to-peer trading service. Electronic Commerce Research and Applications, 12(4), 236-245.

Hair, J., Black, W., Babin, B., Anderson, R., \& Tatham, R. (2006). Multivariate data analysis (6th Edition). Upper Saddle River, NJ: Pearson Prentice Hall.

Harrington, D. (2009). Confirmatory factor analysis. New York, NY: Oxford university press.

Hartmann, P., \& Ibáñez, V.A. (2012). Consumer attitude and purchase intention toward green energy brands: The roles of psychological benefits and environmental concern. Journal of Business Research, 65(9), 1254-1263.

Hassanein, K., \& Head, M. (2007). Manipulating perceived social presence through the web interface and its impact on attitude towards online shopping. International Journal of Human-Computer Studies, 65(8), 689-708.

Herrewijn, L., \& Poels, K. (2013). Putting brands into Play: How game difficulty and player experiences influence the effectiveness of in game advertising. International Journal of Advertising, 32, 17-44.

Hooper, D., Coughlan, J., \& Mullen, M. (2008). Structural equation modelling: Guidelines for determining model fit. Electronic Journal of Business Research Methods, 6(1), 53-60.

Hosseini, S. F., Alakbarli, F., Ghabili, K., \& Shoja, M. M. (2011). Hakim Esmail Jorjani (1042-1137 ad): Persian physician and jurist. Archives of Gynecology and Obstetrics, 284(3), 647-650.

Hsteh, Yi-Chingand Hiang Shu-Ting, (2004), A study of the impacts of service quality on relationship quality in search experince credence sevices. Total Quality Management, 15(1), 43-48

Hu, L. T., \& Bentler, P. M. (1999). Cutoff criteria for fit indexes in covariance structure analysis: Conventional criteria versus new alternatives. Structural Equation Modeling: A Multidisciplinary Journal, 6(1), 1-55.

Hsu, S. H., Whu, S. W., Tsai, C. L., Wu, Y. H., Chen, H. W., \& Hsieh, K. H. (2004). Chitosan as scaffold materials: Effects of molecular weight and degree of deacetylation. Journal of Polymer Research, 11(2), 141-147.

Hsu, C. L., \& Lu, H. P. (2004). Why do people play on-line games? An extended TAM with social influences and flow experience. Information \& Management, 41(7), 853-868.

Hwang, W. Y. (2003). Quantum key distribution with high loss: toward global secure communication. Physical Review Letters, 91(5), 057901.

Hsu, C. L., \& Lu, H.P. (2007). Consumer behavior in online game communities: A motivational factor perspective. Computers in Human Behavior, 23(3), 1642-1659.

Jalilvand, M. R., \& Samiei, N. (2012). The effect of electronic word of mouth on brand image and purchase intention. An empirical study in the automobile industry in Iran. Marketing Intelligence \& Planning, 30(4), 460-476.

Judge, H. G. (1982). The English public school: History and society. History of Education Quarterly, 22(4), 513-525.

Kamaruddin, A. R., \& Mokhlis, S. (2003). Consumer socialization, social structural factors and decision-making styles: A case study of adolescents in Malaysia. International Journal of Consumer Studies, 27(2), 145-156.

Katz, J. N. (2006). Lumbar disc disorders and low-back pain: Socioeconomic factors and consequences. JBJS, 88(2), 2124.

Kim, D. J., Ferrin, D. L., \& Rao, H. R. (2008). A trust-based consumer decision-making model in electronic commerce: The role of trust, perceived risk, and their antecedents. Decision Support Systems, 44(2), 544-564.

Kline, R. B. (2011). Principles and practice of structural equation modeling (3rd edition). The Guilford Press.

Koufaris, M. (2002). Applying the technology acceptance model and flow theory to on-line consumer behavior. Information System Research, 13(2), 205-223.

Kubaş, A., Yılmaz, R., Güt, A., \& Baloğlu, S. (2016). Tekirdağ ilinde bulunan tüketicilerin internet üzerinden satın alma yaklaşımlarının analizi. Social Sciences Research Journal, 5(4), 12-29. 
Lee, M., \& Faber, R. J. (2007). Effects of product placement in on-line games on brand memory. A perspective of the limited-capacity model of attention. Journal of Advertising, 36, 75-90.

Leeraphong, A., Mardjo, A. (2013). Trust and risk in purchase intention through online social network: A focus group study of Facebook in Thailand. Journal of Economics, Business, and Management, 1(4), 314-318.

Lee-Davies, L., Rozuel, C., \& Kakabadse, N. K. (2005). Corporate social responsibility and stakeholder approach: A conceptual review. International Journal of Business Governance and Ethics, 1(4), 277-302.

Legris, P., Ingham, J., \& Collerette, P. (2003). Why do people use information technology? A critical review of the technology acceptance model. Information \& Management, 40(3), 191-204.

$\mathrm{Li}, \mathrm{C}$. (2014). Evaluation of a theoretical model for gamification in workplace is context. University of British Columbia, Doctoral Dissertation. Retrieved April 17, 2020 from https://www.semanticscholar.org/paper/Evaluation-of-aTheoretical-Model-for-Gamification-Li/fc2f2b77f71a78ac24215282c5efd9c099b2e401

Li, P., Li, J., Wu, C., Wu, Q., \& Li, J. (2005). Synergistic antibacterial effects of $\beta$-lactam antibiotic combined with silver nanoparticles. Nanotechnology, 16(9), 1912.

Liu, L. C., Fan, Y., Wu, G., \& Wei, Y. M. (2007). Using LMDI method to analyze the change of China's industrial CO2 emissions from final fuel use: An empirical analysis. Energy Policy, 35(11), 5892-5900.

Liaw, S. S., \& Huang, H. M. (2003)., An investigation of user attitudes toward search engines as an information retrieval tool. Computers in Human Behaviour, 19(6), 751-765.

Lewin, J., Strutton, H. D., \& Taylor, D. (2011). Friends, fans, and followers: Do ads work on social networks? Journal of Advertising Research, 51(1), 258-275.

Lu, L. C., Chang, W. P., \& Chang, H. H. (2014). Consumer attitudes toward blogger's sponsored recommendations and purchase intention: The effect of sponsorship type, product type, and brand awareness. Computers in Human Behavior, 34, 258-266.

MacKenzie, S., Lutz, R., \& Belch, G. (1986). The role of attitude toward the ad as a mediator of advertising effectiveness: A test of competing explanations. Journal of Marketing Research, 23(2), 130-143.

Malhotra, Y., \& Galletta, D. F. (1999). Extending the technology acceptance model to account for social influence: Theoretical bases and empirical validation. In Proceedings of the 32nd Annual Hawaii International Conference on Systems Sciences. 1999. HICSS-32. Abstracts and CD-ROM of Full Papers (14). IEEE.

Marczewski, A. (2013). What's the difference between gamification and serious games? Retrieved April 17, 2020 from http://www.gamasutra.com/blogs/AndrzejMarczewski/20130311/188218/ Whats_the_difference_between_Gamification_and_Serious_Games.php

McGonigal, J. (2011). Reality is Broken: Why games make us better and how they can change the world. New York: Penguin Books.

Moorman, C., \& Zaltman, G. (1992). Relationships between providers and users of market research: The dynamics of trust within and between organizations. Journal of Marketing Research, 29(3), 314-328.

Morosan, C. (2012). Theoretical and empirical considerations of guests' perceptions of biometric systems in hotels: Extending the technology acceptance model. Journal of Hospitality \& Tourism Research, 36(1), 52-84

Morgan, R. M., \& Hunt, S. (1994). The commitment-trust theory of relationship marketing. Journal of Marketing, 58(3), 20-38.

Nelson, N., \& Kuhn, T. (2002). Reengineering identity: A case study of multiplicity and duality in organizational identification. Management Communication Quarterly, 16(1), 5-38.

Pallant, J. (2013). SPSS survival manual. London: McGraw-Hill Education.

Pavlou, P. A. (2003). Consumer acceptance of electronic commerce: Integrating trust and risk with the technology acceptance model. International Journal of Electronic Commerce, 7(3), 101-134.

Park, S. Y. (2009). An analysis of the technology acceptance model in understanding university students' behavioral intention to use e-learning. Educational Technology Society, 12(3), 150-162.

Pikkarainen, T., Pikkarainen, K., Karjaluoto, H., \& Pahnila, S. (2004). Consumer acceptance of online banking: An extension of the technology acceptance model. Internet Research, 14(3), 224-235.

Prendergast, G., Ko, D., \& Siu Yin, V. Y. (2010). Online word of mouth and consumer purchase intentions. International Journal of Advertising, 29(5), 687-708.

Reiss, S. (2000). Who am I? The 16 basic desires that motivate our actions and define our personality. New York: Penguin Publishing. 
The Influence of Gamification on Online Consumers' Attitude and Intention to Purchase Fast Moving Consumer Goods

Ramayah \& Jantan (2003). Intention to Purchase through the World Wide Web (WWW): The Malaysian experience. The Third International Conference on Electronic Commerce Engineering (ICeCE2003), Hangzhou, China.

Ramayah, T., Sarkawi, F., \& Lam, S. C. (2003, October). Attitude and intention to use web-based supply chain management (SCM) among SME's. In Asia Pacific Seminar on E-Customer Relationship Management, Shah Alam, Selangor, Malaysia (pp. 8-9).

Rodrigues, L. F., Costa, C. J., \& Oliveira, A. (2013, July). The adoption of gamification in e-banking. In Proceedings of the 2013 International Conference on Information Systems and Design of Communication (47-55).

Sallam, M. A., \& Algammash, F. A. (2016). The effect of attitude toward advertisement on attitude toward brand and purchase intention. International Journal of Economics, Commerce and Management, 4(2), 509-520.

Saunders, H. D., \& Laudan, L. (2009). Re-thinking the criminal standard of proof: Seeking consensus about the utilities of trial outcomes. International Commentary on Evidence, 7(2), 1-34.

Schreiber, J. B., Nora, A., Stage, F. K., Barlow, E. A., \& King, J. (2006). Reporting structural equation modeling and confirmatory factor analysis results: A review. The Journal of Educational Research, 99(6), 323-338.

Seaborn, K., \& Fels, D. I. (2015). Gamification in theory and action: A survey. International Journal of Human-Computer Studies, 74, 14-31.

Smith, S. M., \& Albaum, G. S. (2005). Fundamentals of Marketing Research. London: Sage.

Soroa-Koury, S., \& Yang, K. C. (2010). Factors affecting consumers' responses to mobile advertising from a social norm theoretical perspective. Telematics and Informatics, 27(1), 103-113.

Song, H., Wang, J., \& Han, H. (2019). Effect of image, satisfaction, trust, love, and respect on loyalty formation for namebrand coffee shops. International Journal of Hospitality Management, 79, 50-59.

Tarkiainen, A., \& Sundqvist, S. (2005), Subjective norms, attitudes and intentions of Finnish consumers in buying organic food. British Food Journal, 107(11), 808-822.

Taherdoost, H. (2016). Validity and reliability of the research instrument; How to test the validation of a questionnaire/survey in a research. SSRN Electronic Journal, 5(3), 28-36.

Tabachnick, B. G., \& Fidell, L. S. (2007). Experimental designs using ANOVA (p. 724). Belmont, CA: Thomson/Brooks/Cole.

Teo, T., \& Noyes, J. (2011). An assessment of the influence of perceived enjoyment and attitude on the intention to use technology among pre-service teachers: A structural equation modeling approach. Computers \& Education, 57(2), 1645-1653.

Van der Heijden, H. (2003). Factors influencing the usage of websites: The case of a generic portal in The Netherlands. Information \& Management, 40(6), 541-549.

Van der Heijden, H., Verhagen, T., \& Creemers, M. (2003). Understanding online purchase intentions: Contributions from technology and trust perspectives. European Journal of Information Systems, 12(1), 41-48.

Venkatesh, V. (2000). Determinants of perceived ease-of-use: Integrating control, intrinsic motivation, and emotion into the technology acceptance model. Information Systems Research, 11, 342-365.

Venkatesh, V., \& Davis, F. D. (2000). A theoretical extension of the technology acceptance model: Four longitudinal field studies. Management Science, 46(2), 186-204.

Wakefield, J. P., \& Moore, D. J. (2011). Designing ambisonic decoders for improved surround sound playback in constrained listening spaces. Retrieved April 18, 2020 from http://eprints.hud.ac.uk/id/eprint/10860/1/AES_London_2011_Speaker_Placement.pdf

West, S. G., Finch, J. F., \& Curran, P. J. (1995). Structural equation models with nonnormal variables: Problems and remedies. In: R. H. Hoyle (Ed.), Structural Equation Modeling: Concepts, Issues and Applications. Newbery Park, CA: Sage

Wen, X., Sun, H., Liu, J., Cheng, K., Zhang, P., Zhang, L., ... \& Leonidas, D. D. (2008). Naturally occurring pentacyclic triterpenes as inhibitors of glycogen phosphorylase: synthesis, structure- activity relationships, and X-ray crystallographic studies. Journal of Medicinal Chemistry, 51(12), 3540-3554.

Werbach, K., \& Hunter, D. (2012). For the win: How game thinking can revolutionize your business. Philadelphia: Wharton Digital Press.

Wise, K., Bolls, P., Kim, H., Venkataraman, A., \& Meyer, R. (2008). Enjoyment of advergames and brand attitudes: The impact of thematic relevance. Journal of Interactive Advertising, 9(1), 14-25.

Wu, J., \& Liu, D. (2007). The effects of trust and enjoyment on intention to play online games. Journal of Electronic Commerce Research, 8(2), 128-140. 
Xu, X. J. (2010) The effect of advertising persuasion. Beijing Technology and Business University (Social Sciences), 25, 7983.

Yang, Y., Asaad, Y., \& Dwivedi, Y. (2017). Examining the impact of gamification on intention of engagement and brand attitude in the marketing context. Computers in Human Behavior, 73, 459-469.

Yalcin, M., Erdogmus, I. E., \& Demir, S. (2009). Using associations to create positive brand attitude for generation $Y$ consumers: Application in fashion retailing. Suleyman Demirel University - The Journal of Faculty of Economics and Administrative Sciences, 14(2), 261-276.

Zichermann, G., \& Cunningham, C. (2011). Gamification by design: Implementing game mechanics in web and mobile Apps. Sebastopol, CA: O'Reilly Media.

Zichermann, G., \& Linder, J. (2013). The gamification revolution. New York: McGraw- Hill Education. 
This Page Intentionally Left Blank 